\title{
HAK ATAS TANAH BAGI PARTAI POLITIK
}

\author{
Agus Sekarmadji \\ Dosen Fakultas Hukum Universitas Airlangga \\ Email: agussekarmadji_unair@yahoo.com
}

\begin{abstract}
Land Law in Indonesia does not clearly specify the political parties as a subject of land rights. There are often the case of land used by the political parties on be half of the Chairman of the party, so that it becomes a problem when the Chairman of the Party out of office as Chairman of the party, because the certificate of the right to land is still listed in his name. This article will elaborate on land rights for political parties and manner of acquisition.
\end{abstract}

Key words: political parties, land rights, acquisition of rights.

\begin{abstract}
Abstrak
Hukum pertanahan di Indonesia tidak secara jelas mencantumkan partai politik sebagai subjek hak atas tanah. Sehingga sering terjadi hak atas tanah yang digunakan oleh partai politik diatasnamakan ketua partai, sehingga menjadi masalah ketika ketua partai tidak menjabat lagi sebagai ketua partai, karena sertifikat hak atas tanahnya masih tercantum atas namanya. Tulisan ini akan menguraikan tentang hak atas tanah bagi partai politik dan tata cara perolehannya.
\end{abstract}

Kata kunci : partai politik, hak atas tanah, perolehan hak.

\section{Latar Belakang}

Pada tahun 2010 diberitakan adanya sengketa tanah antara pengurus salah satu partai politik dengan mantan Ketua DPD sebuah Partai Politik. Dalam kasus tersebut terungkap bahwa kantor DPD Partai tersebut berdiri di atas tanah dengan status hak milik atas nama mantan Ketua DPD Partai tersebut. Setelah tidak lagi menjabat sebagai Ketua DPD, mantan ketua tersebut mengiklankan tanah dan bermaksud menjual kepada pihak lain. Tindakan tersebut dirasakan sangat merugikan pihak DPD karena tanah tersebut diklaim sebagai asset DPD.

Berdasarkan uraian kasus di atas, permasalahan yang dibahas apakah partai politik dapat menjadi subjek hukum hak atas tanah? Apabila dapat jenis hak atas tanah apa yang dapat diberikan kepada Partai Politik tersebut dan bagaimana cara memperolehnya? Untuk membahas permasalahan tersebut maka terlebih dahulu akan dibahas mengenai partai politik di Indonesia, hak-hak atas tanah yang dapat diberikan kepada Partai Politik dan Tata Cara perolehan Hak Atas Tanah Bagi Partai Politik.

\section{Pembahasan}

\section{a. Partai Politik di Indonesia}

Partai politik adalah organisasi yang bersifat nasional dan dibentuk oleh sekelompok warga negara Indonesia secara sukarela atas dasar kesamaan kehendak dan cita-cita untuk memperjuangkan dan membela kepentingan politik anggota, masyarakat, bangsa dan negara, serta memelihara keutuhan Negara Kesatuan Republik Indonesia berdasarkan Pancasila dan Undangundang Dasar Negara Republik Indonesia Tahun 1945 (UUD 1945).

Keberadaan Partai Politik di Indonesia tidak terlepas dari UUD 1945 yang mengamanatkan bahwa kemerdekaan berserikat, berkumpul dan mengeluarkan pendapat merupakan hak 
asasi manusia yang harus dilaksanakan untuk memperkuat semangat kebangsaan dalam Negara Kesatuan Republik Indonesia yang demokratis. Hak untuk berserikat dan berkumpul inilah kemudian diwujudkan dalam pembentukan partai politik. Ketentuan yang mengatur mengenai partai politik diatur dalam Undang-undang Nomor 2 Tahun 2008 tentang Partai politik sebagaimana telah dirubah dengan Undang-undang Nomor 2 Tahun 2011.

Berdasarkan Pasal 2 ayat (1) Undangundang No 2 Tahun 2008 tentang Partai Politik sebagaimana telah dirubah dengan Undangundang Nomor 2 Tahun 2011, partai politik didirikan dan dibentuk oleh paling sedikit 30 orang warga negara Indonesia yang telah berusia 21 tahun. Partai Politik harus harus didaftarkan ke Kementrian Hukum dan HAM untuk menjadi Badan Hukum. Untuk bisa didaftar sebagai Badan Hukum maka Partai Politik harus mempunyai:

1. Akta Notaris pendirian Partai Politik;

2. Nama, Lambang, atau tanda gambar yang tidak mempunyai persamaan pada pokoknya atau keseluruhannya dengan nama, lambang, atau tanda gambar yang telah dipakai secara sah oleh Partai Politik lain sesuai dengan Peraturan Perundang-undangan yang berlaku;

3. Kepengurusan pada setiap provinsi dan paling sedikit $75 \%$ dari jumlah kabupaten/ kota pada provinsi yang bersangkutan dan paling sedikit $50 \%$ dari jumlah kecamatan pada kabupaten/kota yang bersangkutan;

4. Kantor tetap pada tingkat pusat, provinsi, dan kabupaten/kota sampai tahapan terakhir pemilihan umum;

5. Rekening atas nama Partai Politik.

Berdasarkan uraian tersebut di atas nampak bahwa partai politik yang memenuhi syarat dan berstatus sebagai badan hukum, sehingga berhak untuk mempunyai keuangan partai. Pasal 1 angka 5 Undang-undang No 2 Tahun 2008 sebagaimana telah dirubah dengan Undang-undang Nomor 2 Tahun 2011 yang disebut dengan keuangan partai adalah semua hak dan kewajiban partai politik yang dapat dinilai dengan uang, berupa uang, atau barang serta segala bentuk kekayaan yang dimiliki dan menjadi tanggung jawab partai politik. Dengan uraian tersebut maka dapat dipahami bahwa keuangan partai mencakup pula kekayaan yang berupa tanah dengan suatu hak untuk mendirikan kantor tetap baik pada tingkat pusat, provinsi, dan kabupaten/kota.

\section{b. Hak atas Tanah yang Dapat Diberikan Kepada Partai Politik}

Politik hukum agraria nasional dasarnya adalah Pasal 33 ayat (3) UUD 1945 yang berbunyi: Bumi, air dan kekayaan alam yang terkandung di dalamnya dikuasai oleh negara dan dipergunakan untuk sebesar-besar kemakmuran rakyat. Untuk mencapai tujuan tersebut maka diperlukan adanya sarana yang berupa peraturan yang salah satunya adalah Undang-undang Nomor 5 Tahun 1960 (UUPA)

Di dalam Pasal 2 ayat (1) UUPA disebutkan bahwa atas dasar ketentuan dalam Pasal 33 ayat 3 Undang-undang Dasar dan hal-hal sebagaimana yang dimaksudkan dalam Pasal 1, bumi air dan ruang angkasa, termasuk kekayaan alam yang terkandung di dalamnya itu pada tingkatan tertinggi dikuasai oleh Negara, sebagai organisasi kekuasaan seluruh rakyat. Jadi hubungan antara negara dengan tanah adalah hubungan penguasaan.

Atas dasar hak menguasai tersebut maka negara mempunyai wewenang sebagaimana diatur dalam Pasal 2 ayat (2) UUPA yakni:

1. Mengatur dan menyelenggarakan peruntukan, penggunaan, penyediaan dan pemeliharaan bumi, air dan ruang angkasa;

2. Menentukan dan mengatur hubunganhubungan hukum antara orang-orang dengan bumi, air dan ruang angkasa;

3. Menentukan dan mengatur hubunganhubungan hukum antara orang-orang dan perbuatan-perbuatan hukum yang mengenai bumi, air dan ruang angkasa.

Atas dasar hak menguasai dari negara tersebut ditentukan adanya macam-macam hak atas tanah yang dapat dipunyai orang-orang atau badan hukum. Berdasarkan Pasal 4 ayat (2) UUPA Hak atas tanah memberi wewenang untuk mempergunakan tanah yang bersangkutan demikian pula tubuh bumi dan air serta ruang yang ada diatasnya sekedar diperlukan untuk kepentingan yang langsung berhubungan dengan penggunaan tanah itu dalam batas-batas menurut Undang-undang ini 
dan peraturan-peraturan hukum yang lebih tinggi. Berdasarkan ketentuan Pasal 4 ayat 2 tersebut maka hak-hak atas tanah yang dipunyai orangorang dan badan hukum tersebut tetap dibatasi yakni oleh UUPA itu sendiri dan peraturan lain yang lebih tinggi.

Macam hak atas tanah yang dapat diberikan dapat dibedakan seperti yang diatur dalam Pasal 16 ayat (1) UUPA yang terbagi dalam :

1. Hak atas tanah yang bersifat tetap, yaitu hak atas tanah yang keberadaannya tetap diakui dan tidak akan dihapus. Pembuat Undangundang tidak bermaksud untuk menghapus keberadaan hak yang bersifat tetap ini. Hak atas tanah yang bersifat tetap ini meliputi hak milik, hak guna bangunan, hak guna usaha, hak pakai, dan hak sewa untuk bangunan;

2. Hak atas tanah yang bersifat sementara adalah hak atas tanah yang keberadaannya direncanakan akan dihapus. Adanya rencana untuk menghapus hak tersebut karena dinilai mengandung unsur pemerasan. Hak tersebut meliputi hak usaha bagi hasil, gadai tanah pertanian, hak menumpang, hak sewa atas tanah pertanian sebagaimana terdapat dalam Pasal 53 UUPA;

3. Hak atas tanah yang akan ditetapkan dengan Undang-undang. Sebagaimana diketahui bahwa perkembangan pembangunan yang ada dimungkinkan memerlukan hak baru atas tanah. Jika dalam perkembangannya diperlukan hak baru maka berdasarkan Pasal 16 hak tersebut harus diatur dalam bentuk Undang-undang.

Untuk menganalisis hak atas tanah apa yang tepat bagai partai politik, maka akan diuraikan macam-macam hak atas tanah khususnya yang bersifat tetap.

\section{b.1. Hak Milik Atas Tanah}

Berdasarkan Pasal 20 ayat (1) UUPA disebutkan bahwa hak milik adalah hak turun temurun, terkuat dan terpenuh, dengan mengingat ketentuan pasal 6. Yang dimaksud dengan turun-temurun adalah bahwa milik tidak hanya berlangsung selama pemiliknya masih hidup, tetapi dapat dilanjutkan oleh ahli warisnya apabila pemiliknya meninggal dunia. Terkuat artinya jangka waktu hak milik tidak dibatasi. Hal ini berbeda dengan hak guna usaha, hak guna bangunan, maupun hak sewa untuk bangunan yang dibatasi jangka waktunya. Sedangkan terpenuh artinya bahwa hak milik itu memberi wewenang kepada pemiliknya lebih luas jika dibandingkan dengan hak lainnya. Hak milik dapat digunakan untuk tanah pertanian maupun non pertanian. Jadi tidak terbatas seperti halnya Hak Guna Usaha (HGU) maupun Hak Guna Bangunan (HGB). Hak milik dapat menjadi induk dari hak-hak lainnya, maksudnya seorang pemilik tanah bisa memberikan tanahnya kepada pihak lain misalnya hak sewa, membagi hasilkan, menggadaikan. ${ }^{1}$ Namun demikian pemegang hak milik tidaklah berarti bisa seenaknya, namun tetap dibatasi Pasal 6 UUPA yang menyatakan bahwa setiap hak atas tanah mempunyai fungsi sosial.

Berdasarkan Pasal 21 ayat (1) UUPA, yang dapat menjadi subjek hak milik adalah hanya warga negara Indonesia. Jadi pada prinsipnya hanya warga negara Indonesia tunggal yang boleh mempunyai tanah dengan hak milik. Badan hukum tidak boleh mempunyai tanah dengan hak milik, kecuali yang ditunjuk berdasarkan Peraturan Pemerintah. Badan-badan hukum yang dapat mempunyai tanah dengan hak milik sebagaimana disebutkan dalam Pasal 21 ayat (2) tersebut ditentukan dalam Peraturan Pemerintah Nomor 38 Tahun 1963 yaitu :

1. Bank-Bank yang didirikan oleh negara;

2. Perkumpulan-perkumpulan koperasi pertanian yang didirikan berdasarkan Undangundang Nomor 79 Tahun 1958;

3. Badan-badan Keagamaan yang ditunjuk oleh Menteri Dalam Negeri setelah mendengar Menteri Agama;

4. Badan-badan Sosial yang ditunjuk oleh Menteri Dalam Negeri setelah mendengar Menteri Sosial.

Mengenai orang asing yang sesudah berlakunya UUPA, memperoleh hak milik karena pewarisan tanpa wasiat atau percampuran harta karena perkawinan, demikian pula warga negara Indonesia yang mempunyai hak milik dan setelah berlakunya UUPA ini kehilangan kewarganegaraannya, maka mereka wajib melepaskan hak

1 Efendi Parangin, Hukum Agraria Indonesia, Suatu Telaah Dari Sudut Pandang Praktisi Hukum, Rajawali, Jakarta, 1991, hlm. 237. 
itu dalam jangka waktu satu tahun sejak diperolehnya hak tersebut atau hilangnya kewarganegaraannya. Apabila sesudah jangka waktu tersebut lampau, dan hak milik itu tidak dilepaskan, maka hak tersebut hapus karena hukum dan tanahnya menjadi tanah negara, dengan ketentuan bahwa hak-hak pihak lain yang membebaninya tetap berlangsung.

Sebagaimana diuraikan di atas bahwa Partai Politik merupakan badan hukum, akan tetapi tidak termasuk Badan Hukum yang ditetapkan pemerintah sebagai subjek hak milik. Jadi dengan demikian Partai Politik tidak dapat menjadi subjek hak milik atas tanah

\section{b.1.2. Hak Guna Usaha}

Berdasarkan Pasal 28 UUPA jo. Pasal 12 Peraturan Pemerintah Nomor 40 Tahun 1996 hak guna usaha adalah hak untuk mengusahakan tanah yang langsung dikuasai oleh negara guna perusahaan pertanian, perkebunan, perikanan dan peternakan. Hak guna usaha hanya terjadi pada tanah yang langsung dikuasai oleh negara. Namun hal ini tidak menutup kemungkinan mengenai tanah yang tak langsung dikuasai oleh negara, asal dengan syarat khusus yaitu subjek hukum tersebut harus mampu mengubah status tanah dari tanah yang tidak langsung dikuasai oleh negara menjadi tanah yang langsung dikuasai oleh negara, misalnya dengan pengadaan tanah.

Ada beberapa alasan mengapa hak guna usaha tidak dapat terjadi pada hak milik yaitu bahwa peruntukan HGU hanya terbatas bagi perusahaan pertanian, perikanan, dan peternakan, sehingga apabila terjadi pada tanah hak milik maka akan bertentangan dengan Pasal 10 ayat (1) UUPA yang menyatakan bahwa "setiap orang dan badan hukum yang mempunyai sesuatu hak atas tanah pertanian pada asasnya diwajibkan mengerjakan sendiri secara aktif, dengan mencegah cara pemerasan". HGU menurut maksudnya diberikan dalam jangka waktu yang lama. Maka jika seseorang pemilik tanah memberikan hak guna usaha maka pemilik tanah tersebut tidak dapat mengerjakan tanahnya secara aktif.

Adanya batasan peruntukan HGU untuk pertanian, perkebunan, perikanan, dan peternakan tidaklah berarti bahwa pemegang HGU dilarang mendirikan bangunan di atas tanah HGU. Pemegang HGU pada dasarnya masih diberikan kesempatan untuk mendirikan bangunan asal pendirian bangunan itu semata-mata untuk memperlancar usaha pertanian, perikanan, peternakan dan perkebunan.

Yang dapat mempunyai hak guna usaha adalah :

1. Warga negara Indonesia;

2. Badan hukum yang didirikan menurut hukum Indonesia dan berkedudukan di Indonesia.

Dari ketentuan di atas tidak ada keharusan bahwa subjek hukum tersebut harus warga negara Indonesia tunggal sehingga terbuka kemungkinan bagi mereka yang berkewarganegaraan rangkap dapat mempunyai hak guna usaha.

Pemegang Hak guna usaha yang tidak lagi memenuhi syarat sebagaimana disebutkan di atas maka dalam jangka waktu satu tahun wajib melepaskan atau mengalihkan hak guna usaha itu kepada pihak lain yang memenuhi syarat. Apabila dalam jangka waktu tersebut pemegang hak guna usaha tidak melepaskan atau tidak mengalihkan maka hak guna usaha itu hapus karena hukum dan tanahnya menjadi tanah negara.

Sebagaimana telah diuraikan di atas, tanah yang dapat diberikan dengan hak guna usaha adalah tanah negara. Jika tanah yang hendak diberikan dengan hak guna usaha itu adalah tanah negara yang merupakan kawasan hutan, maka pemberian hak guna usaha hanya dapat dilakukan setelah tanah tersebut statusnya harus dikeluarkan sebagai kawasan hutan. Jadi tanah negara yang diberikan dengan hak guna usaha harus bebas dari kepentingan pihak lain. Oleh karena itu apabila tanah itu harus dipergunakan untuk hutan sesuai peraturan yang berlaku, maka tanah tersebut harus terlebih dahulu dikeluarkan dari statusnya sebagai kawasan hutan. ${ }^{2}$

Luas tanah yang dapat diberikan dengan hak guna usaha minimum adalah lima hektar. Sedangkan luas maksimum tanah yang dapat diberikan dengan hak guna usaha kepada perorangan adalah dua puluh lima hektar. Untuk badan hukum HGU dapat diberikan lebih dari 25 hektar yang ditetapkan oleh Menteri Negara Agraria/Kepala

2 Penjelasa n Pasal 4 ayat (2) Peraturan Pemerintah Nomor 40 Tahun 1996 Tentang Hak Guna Usaha, Hak Guna Bangunan Dan Hak Pakai Atas Tanah. 
BPN dengan memperhatikan pertimbangan dari pejabat yang berwenang di bidang usaha yang bersangkutan, dengan mengingat luas yang diperlukan untuk pelaksanaan suatu usaha yang paling berdaya guna di bidang yang bersangkutan.

Hak guna usaha sebagaimana dimaksud di atas diberikan untuk jangka waktu paling lama tiga puluh lima tahun dan dapat diperpanjang untuk jangka waktu paling lama dua puluh lima tahun.

Perpanjangan jangka waktu hak tidaklah menghentikan berlakunya hak yang bersangkutan, melainkan hak itu terus berlangsung menyambung pada jangka waktu hak semula. Hal ini penting artinya untuk kepentingan hak-hak pihak lain yang membebani hak guna usaha, misalnya hak tanggungan, yang akan hapus dengan sendirinya apabila hak guna usaha itu hapus.

Sesudah jangka waktu HGU dan perpanjangannya berakhir, kepada pemegang hak dapat diberikan pembaharuan hak guna usaha di atas tanah yang sama.

Istilah diperbaharui di sini untuk memberikan pertimbangan syarat-syarat yang ditentukan. Dengan digunakannya istilah diperbaharui maka syarat-syarat yang diperlukan dalam hak guna usaha yang baru itu akan berbeda dengan syarat-syarat yang diberikan sebelumnya. Karena lamanya waktu yang telah diberikan dapat. ${ }^{3}$

Dari uraian tersebut diatas nampak bahwa kegunaan HGU hanya diberikan untuk usaha pertanian, perikanan, peternakan dan perkebunan. Dalam kaitannya dengan partai politik maka tidak mungkin diberikan HGU karena tujuan penguasaan tanah oleh Partai Politik semata mata untuk pembangunan kantor Partai Politik tersebut. Jadi walaupun Partai politik merupakan Badan Hukum tapi tidak dapat diberikan HGU karena tujuan Badan Hukum tersebut diluar usaha pertanian, peternakan, perkebunan dan perikanan.

\section{b.3. Hak Guna Bangunan}

Hak guna bangunan (HGB) adalah hak untuk mendirikan dan mempunyai bangunanbangunan atas tanah yang bukan miliknya sendiri. Dari pengertian ini maka pemegang HGB diberi kewajiban untuk mendirikan dan mempunyai bangunan diatas tanah Hak Guna Bangunan tersebut. Pemegang hak guna bangunan tidak boleh menyewakan tanah hak guna bangunan kepada pihak lain. Akan tetapi dalam hal tanah sudah didirikan bangunan dan kemudian bangunan itu disewakan kepada pihak lain maka tidak menyalahi ketentuan yang telah digariskan kepada pemegang hak guna bangunan karena yang disewakan bukanlah hak atas tanahnya tetapi bangunannya.

Dalam praktik sering terjadi mereka yang telah mendapatkan HGB tidak pernah mendirikan bangunan diatasnya akan tetapi justru menyewakannya kepada pihak lain. Hal ini jelas tidak sesuai dengan tujuan diberikannya HGB tersebut.

Yang dapat menjadi pemegang hak guna bangunan adalah :

1. Warga Negara Indonesia;

2. Badan hukum yang didirikan menurut hukum Indonesia dan berkedudukan di Indonesia. Termasuk pengertian badan hukum adalah semua lembaga yang menurut peraturan yang berlaku diberi status sebagai badan hukum misalnya perseroan terbatas, koperasi, perhimpunan, yayasan tertentu, dan lain-lain

Pemegang hak guna bangunan yang tidak lagi memenuhi syarat di atas dalam jangka waktu satu tahun wajib melepaskan atau mengalihkan hak atas tanah tersebut kepada pihak lain yang memenuhi syarat. Apabila dalam jangka waktu satu tahun tersebut pemegang hak tidak melepaskan atau mengalihkan haknya maka hak tersebut hapus karena hukum.

Berdasarkan uraian tersebut maka badan hukum dapat menjadi subjek HGB, sehingga memungkinkan bagi partai politik untuk dapat mempunyai HGB. Jika ditinjau dari tujuan penguasaan tanah bagai Partai Politik untuk mendirikan dan mempunyai bangunan yang digunakan untuk kantor sekretariatan Partai, maka saya berpendapat bahwa Partai Politik dapat diberikan hak atas tanah dengan status HGB.

\section{b.4. Hak Pakai Atas Tanah}

Hak pakai adalah hak untuk menggunakan dan atau memungut hasil dari tanah yang dikuasai langsung oleh negara, atau tanah milik orang lain

3 Sri Hajati dan Agus Sekarmadji, Politik Hukum Pertanahan, Airlangga University Press, 2011, hlm. 30. 
yang memberi wewenang dan kewajiban yang ditentukan dalam keputusan pemberiannya atau dalam perjanjian dengan pemilik tanahnya, yang bukan perjanjian sewa menyewa atau perjanjian pengelolahan tanah.

Dari pengertian hak pakai tersebut maka dapat dikatakan bahwa hak pakai dapat diberikan untuk tujuan mendirikan bangunan dan ada pula hak pakai yang diberikan untuk tujuan pertanian, yang mana wewenang dan kewajibannya tergantung pada keputusan pemberiannya atau dalam perjanjian dengan pemilik tanah.

Dalam pasal 39 Peraturan Pemerintah Nomor 40 Tahun 1996 disebutkan bahwa yang dapat memiliki hak pakai adalah :

1. Warga Negara Indonesia;

2. Badan hukum yang didirikan menurut hukum Indonesia dan berkedudukan di Indonesia;

3. Departemen, lembaga Pemerintah Non Departemen dan pemerintah daerah;

4. Badan-badan Keagamaan dan sosial;

5. Orang asing yang berkedudukan di Indonesia;

Orang asing yang dianggap berkedudukan di Indonesia adalah orang asing yang kehadirannya di Indonesia memberikan manfaat bagi pembangunan nasional;

6. Badan hukum asing yang mempunyai perwakilan di Indonesia;

7. Perwakilan Negara asing dan perwakilan badan Internasional.

Pemegang hak pakai yang tidak lagi memenuhi syarat sebagaimana disebutkan di atas dalam waktu satu tahun wajib melepaskan atau mengalihkan hak itu kepada pihak yang memenuhi syarat. Apabila dalam jangka waktu satu tahun tersebut haknya tidak dilepaskan atau tidak dialihkan, maka hak tersebut hapus karena hukum dengan ketentuan hak-hak pihak lain yang terkait diatas tanah tersebut tetap diperhatikan.

Dari uraian tersebut di atas maka bagi partai politik sebagai suatu badan hukum sangat dimungkinkan untuk dapat diberikan Hak Pakai khususnya hak pakai yang diperuntukkan bagi pendirian bangunan.

\section{b.5. Hak Sewa Untuk Bangunan}

Hak sewa untuk bangunan (HSUB) diatur dalam Pasal 44-45 UUPA. HSUB adalah hak untuk mempergunakan tanah milik orang lain untuk keperluan bangunan, dengan membayar kepada pemiliknya sejumlah uang sebagai sewa. Tanah yang disewa berstatus hak milik.

HSUB ini tidak sama dengan hak sewa atas bangunan (HSAB). Dalam HSUB ini yang disewa adalah tanah kosong, selanjutnya pihak penyewa mendirikan bangunan di atas HSUB tersebut, sedangkan HSAB adalah hak sewa atas bangunan dalam arti yang menjadi objek sewa adalah bangunan. Sebagaimana diketahui di Indonesia menganut asas pemisahan horizontal. Atas dasar asas ini, maka pemilik tanah tidak dengan sendirinya merupakan pemilik bangunan, sehingga bangunan dapat dijadikan objek tersendiri yang terpisah dari tanahnya. Dalam HSAB ini tidak mensyaratkan harus hak milik, sedangkan HSUB mengharuskan pihak penyewa adalah pemilik tanah. ${ }^{4}$

HSUB terjadi atas dasar perjanjian dengan pemilik tanah dengan pihak penyewa. Jangka waktu HSUB tergantung pada kesepakatan para pihak. Apabila jangka waktu HSUB habis, maka HSUB habis juga habis. HSUB bukan objek pendaftaran tanah dan bukan merupakan objek hak tanggungan.

Yang dapat menjadi pemegang hak sewa untuk bangunan adalah:

1. WNI;

2. Orang asing yang berkedudukan di Indonesia

3. Badan Hukum Indonesia;

4. Badan Hukum Asing yang mempunyai perwakilan di Indonesia.

Dari uraian tersebut maka Partai Politik sebagai Badan Hukum dapat memenuhi syarat untuk mempunyai HSUB

\section{c. Perolehan Hak Atas Tanah Bagi Partai Politik}

Partai politik yang hendak mempunyai hak atas tanah dapat melakukan perolehan hak atas tanah dengan cara jual beli, tukar menukar dan cara pelepasan hak yang diikuti permohonan hak atas tanah. 


\section{c.1. Jual Beli Hak Atas Tanah.}

Cara perolehan hak atas tanah dengan jual beli harus tetap berpegang pada kaidah-kaidah jual beli yang ditentukan dalam hukum pertanahan. Sebagaimana diketahui bahwa hukum pertanahan kita dasarnya adalah hukum adat. Dalam hukum adat maka syarat sahnya jual beli tanah adalah terpenuhinya tiga unsur, yakni tunai, riil dan terang. ${ }^{5}$ Yang dimaksud dengan tunai adalah bahwa penyerahan hak oleh penjual dilakukan bersamaan dengan pembayaran oleh pembeli dan seketika itu juga hak sudah beralih. Harga yang dibayarkan itu tidak harus lunas, selisih harga dianggap sebagai utang pembeli kepada penjual yang termasuk dalam lingkup hukum utang piutang. Sifat riil berarti bahwa kehendak yang diucapkan harus diikuti dengan perbuatan nyata, misalnya dengan telah diterimanya uang oleh penjual dan dibuatnya perjanjian di hadapan kepala desa. Dalam putusan Mahkamah Agung Tanggal 4 Desember 1957 Nomor 271 K/Sip/1956 menjelaskan sifat riil perjanjian jual beli menurut hukum adat sebagai berikut: "Sifat riil hanya berarti bahwa dengan mengucapkan kata-kata dengan mulut saja, belumlah terjadi perjanjian jual beli, namun harus sudah terjadi penulisan kontrak jual beli di muka Kepala kampung serta penerimaan harga barangnya oleh penjual, yang dinyatakan oleh penjual secara riil pelaksanaan maksudnya untuk memindahkan hak miliknya kepada pembeli"

Perbuatan hukum jual beli tanah tersebut disebut terang kalau dilakukan di hadapan kepala desa untuk memastikan bahwa perbuatan itu tidak melanggar ketentuan hukum yang berlaku. ${ }^{7}$

Senada dengan pendapat tersebut di atas Hilman Hadikusumah mengemukakan bahwa hukum adat bercorak serba konkrit, serba jelas artinya hubungan-hubungan hukum yang dilakukan tidak serba samar-samar, antara kata dan perbuatan berjalan serasi, jelas dan nyata. ${ }^{8}$ Prinsip jual beli dalam hukum adat tersebut kemudian diangkat dalam hukum tanah nasional sebagai- mana diatur dalam Pasal 37 ayat (1) Peraturan Pemerintah Nomor 24 Tahun 1997 yang menyatakan bahwa peralihan hak atas tanah dan hak milik atas satuan rumah susun melalui jual beli, tukar menukar, hibah, pemasukan dalam perusahaan dan perbuatan hukum pemindahan hak lainnya, kecuali pemindahan hak melalui lelang hanya dapat didaftarkan jika dibuktikan dengan akta yang dibuat oleh PPAT yang berwenang menurut ketentuan Peraturan Perundang-undangan yang berlaku. Senada dengan pendapat diatas, Boedi Harsono mengemukakan bahwa dalam memenuhi kebutuhan masyarakat modern yang terbuka lembaga jual beli tanah mengalami modernisasi dan penyesuaian, tanpa mengubah hakikatnya sebagai perbuatan hukum pemindahan hak atas tanah dengan pembayaran harganya secara tunai, serta sifat dan cirinya sebagai perbuatan riil dan terang. ${ }^{9}$ Jual beli berdasarkan Pasal 37 diatas harus dibuktikan dengan akta PPAT. Hal tersebut merupakan suatu perubahan yang bertujuan untuk meningkatkan mutu alat bukti perbuatan hukum yang dilakukan, yang menurut hukum adatnya masyarakat yang terbatas lingkup personal dan teritorialnya, cukup dibuatkan aktanya oleh penjual sendiri dan diketahui oleh Kepala Desa/ Adat. Perubahan tata cara ini bukan meniadakan ketentuan hukum adat yang mengatur segi materiil lembaga jual beli tanah. ${ }^{10}$

Dalam jual beli hak atas tanah maka harus diperhatikan apakah pembeli dapat menjadi subjek hak atas tanah yang akan dibelinya. Hal ini harus diperhatikan karena tidak semua subjek hukum dapat menjadi subjek dari hak atas tanah tertentu. Dengan kata lain dapat dijelaskan bahwa masing-masing hak atas tanah telah ditentukan subjek hukumnya.

Dalam kaitannya dengan partai politik, jika akan memperoleh hak atas tanah dengan cara jual beli maka tanah yang akan dibeli misalnya berstatus HGB. Jika status tanahnya hak milik maka tidak dapat dilakukan karena partai politik bukan subjek hak milik.

\footnotetext{
Maria SW Sumarjono, Kebijakan Pertanahan Antara Regulasi dan Implementasinya, Penerbit Buku Kompas, Jakarta, 2001. hlm.119. Mahadi, Uraian Singkat Tentang Hukum Adat Sejak RR Tahun 1854, Penerbit Alumni, Bandung, 1991, hlm.119. 


\section{c.2. Tukar Menukar Hak Atas Tanah}

Dalam perolehan tanah bagi partai politik dimungkinkan adanya tukar menukar. Dalam pelaksanaan tukar menukar hak atas tanah pada prinsipnya sama dengan pelaksanaan jual beli yakni harus dibuat dengan akta PPAT. Seperti halnya dalam jual beli bahwa pelaksanaan tukar menukar hak atas tanah juga harus tetap memperhatikan apakah para pihak yang melakukan tukar menukar tersebut dapat menjadi subjek hak atas tanah yang akan ditukarkan. Hal ini perlu mendapat perhatian karena tidak semua subjek hukum dapat menjadi subjek hak atas tanah tertentu.

Misalnya subjek yang dapat menjadi subjek hak milik adalah warga negara Indonesia dan badan hukum tertentu yang diatur dalam Peraturan Pemerintah Nomor 38 Tahun 1963. Sedangkan untuk Hak Guna Usaha dan Hak Guna Bangunan subjeknya adalah Warga Negara Indonesia dan badan hukum Indonesia. Jadi jangan sampai terjadi tukar menukar antara badan hukum yang tidak ditunjuk oleh Peraturan Pemerintah Nomor 38 Tahun 1963, melakukan tukar menukar dengan warga negara Indonesia yang mempunyai hak milik atas tanah. Sebab hal ini apabila dilakukan akan berakibat batal demi hukum sebagaimana diatur dalam Pasal 26 ayat (2) UUPA. Selain itu perlu juga diperhatikan apakah sifat dari hak atas tanah itu juga dapat dipindahtangankan atau tidak.

Sebagaimana diketahui bahwa hak pakai atas tanah dapat dikelompokan menjadi dua yaitu hak pakai yang menurut sifatnya mudah dipindahtangankan dan hak pakai yang sifatnya tidak dapat dipindahtangankan. Dalam Pasal 45 ayat (3) Peraturan Pemerintah Nomor 40 tahun 1996 ditentukan bahwa hak pakai yang diberikan untuk jangka waktu yang tidak ditentukan selama dipergunakan untuk keperluan tertentu diberikan kepada : Departemen, Lembaga Pemerintah Non Departemen, dan Pemerintah Daerah, Perwakilan Negara Asing dan Perwakilan Badan Internasional, serta badan keagamaan dan badan sosial. Dalam Penjelasan Pasal 45 disebutkan bahwa Hak pakai yang diberikan untuk waktu yang tidak ditentukan selama tanahnya dipergunakan untuk keperluan tertentu tidak dapat dialihkan kepada pihak lain, akan tetapi dapat dilepaskan oleh pemegang haknya, sehingga menjadi tanah negara untuk kemudian dimohon dengan hak baru oleh pihak lain tersebut. Jadi hak pakai yang demikian itu tidak dapat dilakukan tukar menukar.

Sebagaimana disebutkan di atas, bahwa hak atas tanah yang mungkin bagi partai politik adalah HGB, Hak Pakai dan Hak Sewa Untuk Bangunan. Akan tetapi dalam kaitannya dengan memperoleh tanah dengan cata tukar menukar maka perlu diperhatikan sifat hak tersebut apakah memungkinkan untuk dipindahtangankan atau tidak. Jika menurut sifatnya tidak dapat dipindahtangankan maka tidak dapat dilakukan tukar menukar.

\section{c.3. Pelepasan Hak}

Perolehan tanah selain dengan cara jual beli, tukar menukar juga dapat dilakukan dengan pelepasan hak yang diikuti dengan permohonan hak oleh pihak yang memerlukan. Berdasarkan Pasal 1 angka 3 Kepusan Menteri Negara Agraria/ Kepala BPN Nomor 21 Tahun 1994 yang dimaksud pelepasan atau penyerahan hak atas tanah adalah kegiatan melepaskan hubungan hukum antara pemegang hak atas tanah dengan tanah yang dikuasainya dengan memberikan ganti kerugian atas dasar musyawarah. Dari ketentuan tersebut nampak bahwa pelaksanaan pelepasan dilakukan apabila telah terjadi adanya kesepakatan mengenai bentuk dan besarnya ganti kerugian antara pemegang hak atas tanah dengan pihak yang memerlukan tanah. Dengan dilepaskannya hak atas tanah tersebut bukan berarti tanah tersebut langsung menjadi hak dari pihak yang memerlukan, akan tetapi status tanah tersebut menjadi tanah negara dalam arti bahwa tanah tersebut dikuasai penuh oleh negara karena belum ada hak-hak atas tanah tertentu yang membebaninya.

Dengan status tanah negara tersebut maka memberi kewajiban bagi pihak yang memerlukan untuk mengajukan permohonan hak kepada pejabat yang berwenang. Pelepasan hak merupakan perbuatan sepihak dari pegang hak atas tanah dengan demikian tidak dapat disamakan dengan peralihan hak. Dengan demikian tidak diperlukan adanya akta pemindahan hak yang dibuat oleh PPAT. ${ }^{11}$ 
Secara garis besar pelaksanaan pelepasan hak atas tanah dapat diuraikan berikut ini:

1. Pihak yang memerlukan tanah melakukan musyawarah dengan pemegang hak atas tanah untuk menentukan bentuk dan besarnya ganti kerugian;

2. Terjadi kesepakatan dalam menentukan bentuk dan besarnya ganti kerugian;

3. Pelaksanaan pelepasan hak atas tanah oleh pemegang hak atas tanah dengan cara membuat surat pernyataan pelepasan hak atas tanah atau dapat pula dilakukan dengan akta notaris, sekaligus dilakukan penyerahan ganti kerugian secara langsung oleh pihak yang memerlukan tanah kepada pihak yang memerlukan tanah;

4. Berdasarkan Pasal 51 Peraturan Kepala BPN Nomor 3 Tahun 2007. bersamaan dengan pembuatan surat pernyataan pelepasan hak atas tanah tersebut maka yang berhak atas ganti kerugian wajib menyerahkan dokumendokumen berikut ini.

a. Sertifikat hak atas tanah dan atau dokumen asli pemilikan dan penguasaan tanah.

b. Akta-akta perbuatan hukum lainnya yang berkaitan dengan tanah yang bersangkutan.

c. Akta-akta lain yang berhubungan dengan tanah yang bersangkutan.

d. Surat pernyataan yang diketahui oleh Kepala Desa/ Lurah setempat atau yang setingkat dengan itu yang menyatakan bahwa tanah tersebut adalah benar kepunyaan yang bersangkutan.

e. Kepala Kantor Pertanahan Kabupaten/ Kota mencatat hapusnya hak atas tanah yang dilepaskan atau diserahkan pada buku tanah, sertifikat, dan daftar umum pendaftaran tanah lainnya. Dalam hal tanah yang diserahkan belum bersertifikat, pada asli surat-surat tanah yang bersangkutan oleh Kepala Kantor Pertanahan dicatat bahwa hak atas tanah tersebut telah dilepaskan, untuk di daftar dalam buku tanah, dan selanjutnya pada buku administrasi di Desa yang bersangkutan dicoret oleh Kepala Desa dan dicatat bahwa tanah tersebut telah dilepaskan.

Setelah adanya pelepasan hak atas tanah tersebut maka selanjutnya permohonan hak atas tanah oleh pihak yang memerlukan tanah kepada Badan Pertanahan Nasional sebagaimana diatur dalam Permen Agraria/Kepala BPN Nomor 9 Tahun 1999. Pejabat yang berwenang sebagaimana diatur dalam Permen Agraria/Kepala BPN Nomor 1 Tahun 2011 akan memberikan Surat Keputusan Pemberian Hak Atas Tanah (SKPH).

Atas dasar SKPH tersebut maka pihak yang memperoleh SKPH berkewajiban untuk melakukan pendaftaran hak atas tanah untuk selanjutnya dikeluarkan sertifikat sebagai alat pembuktian hak. Dengan dilakukan pendaftaran tersebut maka pemegang hak akan mendapatkan kepastian hukum.

\section{Kesimpulan}

Berdasarkan Undang-undang Nomor 2 Tahun 2008 tentang partai politik sebagaimana telah dirubah dengan Undang-undang Nomor 2 Tahun 2011, Partai Politik di berikan status Badan Hukum. Dengan status tersebut maka Partai Politik dapat menjadi subjek hak atas tanah. Dengan memperhatikan bahwa penguasaan tanah oleh Partai Politik untuk Kantor sekretariatan maka hak atas tanah yang dapat diberikan adalah HGB, Hak Pakai atau Hak Sewa Untuk Bangunan. Tatacara perolehan hak atas tanah bagi Partai Politik dapat dilakukan dengan cara jual beli, tukar menukar dan cara pelepasan hak yang diikuti dengan permohonan hak kepada pejabat yang berwenang. Dalam menentuan cara mana yang akan dilakukan maka harus diperhatikan subjek hak dan sifat hak tersebut apakah memungkinkan untuk dipindahtangankan atau tidak. 


\section{DAFTAR PUSTAKA}

Buku

Harsono, Boedi, 1994, Hukum Agraria Indonesia, Sejarah Pembentukan Undangundang Pokok Agraria, Isi Dan Pelaksanaannya, Djambatan, Jakarta. , 2006, Hukum Agraria Indonesia, Himpunan Peraturan-Peraturan Hukum Tanah, Djambatan, Jakarta.

Hajati, Sri dan Agus Sekarmadji, 2011, Politik Hukum Pertanahan, Airlangga University Press, Surabaya.

Hilman Hadikusumah, 1980, Pokok-Pokok Pengertian Hukum Adat, Alumni, Bandung.

Mahadi, 1991, Uraian Singkat Tentang Hukum Adat Sejak RR Tahun 1854, Penerbit Alumni, Bandung.

Sekarmadji, Agus, 2010, Prinsip-Prinsip Hukum Perolehan Hak Atas Tanah Dalam Rangka Pembangunan Perumahan, Disertasi, Pascasarjana, Universitas Airlangga, Surabaya.

Sumardjono, Maria S.W, 2001, Kebijakan Pertanahan Antara Regulasi Dan Implementasinya, Panerbit Kompas, Jakarta.

\section{Peraturan Perundang-undangan}

Undang-undang Nomor 5 Tahun 1960, Tentang Peraturan Dasar Pokok-Pokok Agraria, Lembaran Negara Republik Indonesia 1960 Nomor 104, Tambahan Lembaran Negara Republik Indonesia Nomor 2043

Peraturan Pemerintah Nomor 40 Tahun 1996 Tentang Hak Guna Usaha, Hak Guna Bangunan Dan Hak Pakai Atas Tanah, Lembaran Negara Republik Indonesia
1996 Nomor 58, Tambahan Lembaran Negara Republik Indonesia Nomor 3643 Peraturan Pemerintah Nomor 24 Tahun 1997 Tentang Pendaftaran Tanah, Lembaran Negara Republik Indonesia 1997 Nomor 50, Tambahan Lembaran Negara Republik Indonesia Nomor 3696

Peraturan Pemerintah Nomor 40 Tahun 1994 Tentang Rumah Negara, Lembaran Negara Republik Indonesia 1994 Nomor 69, Tambahan Lembaran Negara Republik Indonesia Nomor 3573

Peraturan Menteri Negara Agraria/Kepala Badan Pertanahan Nasional Nomor 1 Tahun 2011 Tentang Pelimpahan Kewenangan Dan Pembatalan Keputusan Pemberian Hak Atas Tanah Negara.

Peraturan Menteri Negara Agraria /Kepala Badan Pertanahan Nasional Nomor 9 Tahun 1999 Tentang Tata Cara Pemberian Dan Pembatalan Hak Atas Tanah Negara Dan Hak Pengelolaan.

Peraturan Kepala Badan Pertanahan Nasional Nomor 3 Tahun 2007 Tentang Ketentuan Pelaksanaan Peraturan Presiden Nomor 36 Tahun 2005 Tentang Pengadaan Tanah Bagi Pelaksanaan Pembangunan Untuk Kepentingan Umum Sebagaimana Telah Dirubah Dengan Peraturan Presiden Nomor 65 Tahun 2006.

Keputusan Menteri Negara Agraria/Kepala Badan Pertanahan Nasional Nomor 21 Tahun 1994 Tentang Tata Cara Perolehan Tanah Bagi Perusahaan Dalam Rangka Penanaman Modal. 